\title{
SYNCHRONIZATION BETWEEN PERFORMANCE INDICATORS IN BUKITTINGGI RPJMD AND THE SUSTAINABLE DEVELOPMENT GOALS
}

\section{SINKRONISASI ANTARA INDIKATOR KINERJA DALAM RPJMD BUKITTINGGI DENGAN TUJUAN PEMBANGUNAN BERKELANJUTAN}

\author{
Gina Havieza Elmizan ${ }^{1)}$, Suhairi ${ }^{2)}$, dan Fauzan Misra ${ }^{3)}$ \\ 1,2,3 Magister Akuntansi, Universitas Andalas \\ Gedung III Fakultas Ekonomi, Kampus Unand Limau Manis Padang 25163 \\ Email: gelmizan@gmail.com, Phone: +6282391856315
}

Naskah Masuk: 30-4-2020

Naskah Diterima: 16-5-2020

Naskah Disetujui: 3-6-2020

\begin{abstract}
ABSTRAK
Indonesia telah menyepakati dan telah menyusun aturan-aturan terkait untuk menyelaraskan arah pembangunan nasional dengan SDGs, hingga ke level daerah, sesuai juga dengan arahan UCLG ASPAC untuk melokalkan SDGs. Akan tetapi, usaha penyelarasan tersebut baru pada level provinsi dan masih dalam tahap perencanaan meskipun berjalannya SDGs sudah sepertiga periode. Penelitian ini bertujuan untuk menelisik upaya-upaya yang telah dilakukan Pemerintah Kota Bukittinggi dalam menyelaraskan RPJMD 2016-2021 dengan SDGs. Pendekatan kualitatif dengan metode studi kasus oleh Yin (2018) digunakan dalam penelitian ini, dengan teknik pengambilan data berupa komparasi dokumentasi RPJMD dan SDGs. Ditemukan dari 17 tujuan SDGs, RPJMD Kota Bukittinggi telah sinkron $76 \%$ dengan tujuan SDGs atau dengan total 38 indikator kinerja dengan distribusi yang berbeda ke masing-masing tujuan SDGs. SDGs dengan indikator yang paling selaras / sinkron dengan RPJMD Bukittinggi ada di SDGs 16, dan yang paling tidak sinkron adalah SDGs nomor 7, 14, 15 dan 17.
\end{abstract}

Kata Kunci: melokalkan SDGs, sinkronisasi pembangunan, RPJMD

\section{ABSTRACT}

Indonesia agreed and has compiled related rules to be able to align the direction of national development with SDGs, up to the regional level, following UCLG ASPAC directives to localize SDGs. However, the alignment effort is only at the provincial level and still in the planning stage despite the running of SDGs nearly reached its one-third period. This research aims to trace the efforts of the Bukittinggi Government in synchronizing RPJMD for 2016-2021 with SDGs. A qualitative approach with the case study method by Yin (2018) was used in this study, with data collection techniques in the form of documentation comparison between RPJMD and SDGs. It is found that out of 17 goals of the SDGs, the Bukittinggi RPJMD synchronized $76 \%$ of SDGs goals or with a total of 38 performance indicators with different distributions to the SDGs goals. The SDGs with the most aligned/synchronous indicators with Bukittinggi RPJMD are in SDGs number 16, and the most out of sync goals are to SDGs number 7, 14, 15, and 17.

Keywords: localizing SDGs, development synchronization, RPJMD 


\section{BACKGROUND}

Sustainable development goals (SDGs) are global development concepts that have replaced the old concept of millennium development goals (MDGs) since the end of the MDGs in 2015. The United Nations designed and agreed that within 15 years (2016-2030), the UN members will reach 17 goals with a total of 169 targets and 241 indicators. Indonesia as a member of the UN, in the High-Level Political Forum meeting on SGDs in New York in 2017, through its representative said that Indonesia had included 94 SDGs performance targets (55.62\% of SDGs targets) in the National Medium-Term Development Plan / RPJMN (Kementerian Luar Negeri Republik Indonesia, 2019).

In supporting the coordination of the achievement of SGDs at the regional level in Asia Pacific countries, the United City and Local Government Asia Pacific (UCLG-ASPAC) was formed in 2018. Then UCLG-ASPAC and a group of local and regional government organizations worldwide gathered in the Global Task Force of the Local and Regional Government. The forum aims to agree that the achievement of SDGs depends on requiring a sense of full ownership of the Global Task Force working area that aims to localize SDGs. Local and regional governments around the world also believe that they have a key role in triggering this sense of ownership, and are responsible for driving implementation by integrating various SDGs on the local ground and ensuring cohesion within their respective work areas.

The very concept of sustainable development is defined as a plan to fulfill the need of the present without harming the right of the future generation (Sari \& Stevani, 2020). Despite the significant efforts made by the cities, regions, and networks to raise awareness and foster a sense of real ownership to localize SDGs, each local government is at a different stage in the process of localizing SGDs. For Indonesia, the effort to localize SDGs has been regulated, both in Presidential Regulation of the Republic of Indonesia Number 59 of 2017 concerning the Implementation of Achievement of Sustainable Development Goals, and in its derivative regulations in the Minister of National Development Planning / Head of the Badan Perencanaan Pembangunan Nasional (BAPPENAS, National Development Planning Agency) of the Republic of Indonesia 
Number 7 of 2018 concerning Coordination, Planning, Monitoring, Evaluating and Reporting on the Implementation of Sustainable Development Goals.

The first process of localizing SDGs in Indonesia is to align SDGs' achievement with national development. The local governments are required by the Presidential Regulation and the Ministry Regulation to align their work programs with targets stated in SDGs by preparing a special document under the coordination of BAPPENAS and BAPPEDA (Local Development Planning Agency) named Regional Action Plan for Sustainable Development Goals (RAD-TPB). The RAD-TPB document refers to similar action plan documents at the national level (namely the National Action Plan for Sustainable Development Goals / RAN-TPB). However, so far, the government has only been ready in the design stage of coordinating the action plan at the national level. The RAN-TPB documents required by the new Presidential Regulation are just announced to the public on June 5, 2018 (Kementerian Perencanaan Pembangunan Nasional Republik Indonesia, 2018). As for the regional level, the obligation to prepare provincial-level RAD-TPB documents is valid no later than 12 months after the issuance of Presidential Regulation Number 59 of 2017. Out of the 35 provinces in Indonesia, only 19 provinces had RAD-TPB as of 2 May 2019 (Salsabila, 2019). This condition is considered by researchers to be quite a time consuming, just for the planning stage, not to mention how to assess the extent of efforts to localize SDGs in Indonesia for the current year, which is already almost one-third of the way (2016-2020).

According to Marlius \& Putra, (2018). a strategy is a choice about what the organization wants to achieve in the future and how to achieve the desired direction. Theoretically, strategic development planning requires planners to consider internal factors (strengths and weaknesses) and external (opportunities and challenges) that affect development in the preparation of development planning documents (Lidya, 2019; Hidayah, Mulatsih, \& Purnamadewi, 2019). Patiung (2019) and Alfa (2019) says that there should be synergy in planning policies related to SDGs. SDGs is one of the external factors that are taken into consideration 
in the preparation of the RPJMD. However, the regional development strategic planning process is not just considering one external factor. Many other external factors (e.g. ASEAN Economic Community, national and provincial development directions), as well as the internal factors (e.g. demographics, resources, regional issues in various aspects of development) during processes, should be considered to be synchronized with regional development targets.

One goal of the SDGs is about reducing poverty (Wahyuni \& Damayanti, 2014; Saragih, 2014; Lisna, et. al, 2013). We can see from Figure 1 that there is an interesting phenomenon of poverty in the last 10 years in 5 big cities in West Sumatera with the total of poor citizens below 10.000 people.

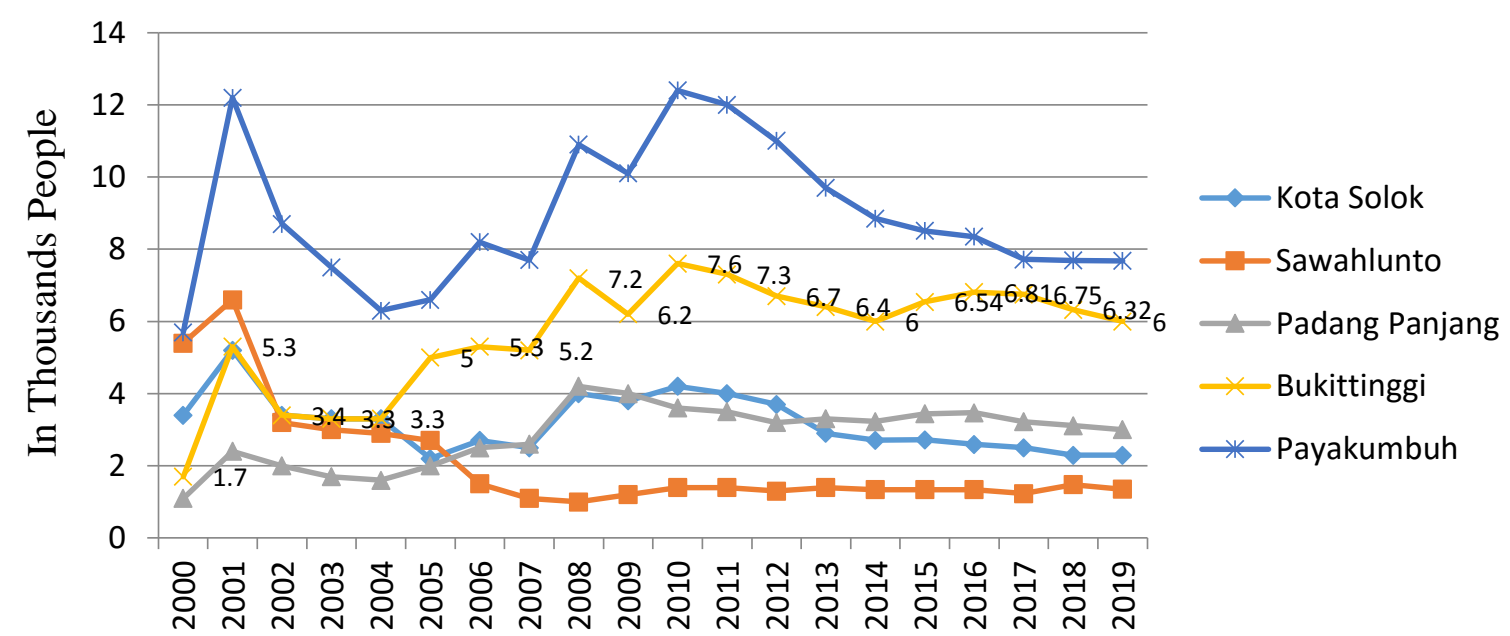

Figure 1. Numbers of Poor Citizens in 5 Cities with Less Than 10 Thousands Poor Citizens in West Source: BPS West Sumatra Sumatra

Figure 1 shows an interesting facts about poverty in the cities with less than 10.000 poor citizens in West Sumatra. Two cities, i.e. Padang Panjang, Sawahlunto and Solok, have a decreasing number of poor citizens. Meanwhile the other three cities show an increase in number of poor citizen, with different change in each city. The highest increase in change of number of poor citizens is shown by the Bukittinggi, i.e. from 1.7 thousands in 2000 to 6 thousands in 2019.

Bukittinggi has an eye-catching increase in numbers of poor citizens. The city should have outlined efforts to achieve SDGs in its planning documents and carried it out the preparation of the RPJMD (Local Medium-Term Development Plan), which includes 
performance indicators that are in line with the development objectives stated in the SDGs. However, the significant increase in a poverty indicator explained how the Bukittinggi city is an interesting research sample to analyze the synchronization efforts of SDGs with the city's RPJMD. More over, after analizing the Bukittinggi RPJMD, the effort to synchronize to SDGs is shown only by less than 2 pages of telling which missions of Bukittinggi RPJMD are in sync with SDGs. There is no further elaboration of which target of SDGs are in sync with the development target in Bukittinggi RPJMD.

Examining the synchronization of SDGs with the Bukittinggi RPJMD is a novelty of this research. Previous researches either explain the SDGs localization theoritically (Tjandradewi \& Srinivas, 2018; Patole, 2018), measure the SDGs achievements in national level (Badan Pemeriksa Keuangan RI, 2018; Fauzi \& Oxtavianus, 2014), or do synchonization of SDGs and RPJMD in other provinces in Indonesia (Pribadi, 2017; Surya, 2018; Sofianto, 2019). None of the previous researches has discussed cities in West Sumatra. In addition, this research contributes to the research on efforts to localize SDGs at the local level, especially in Bukittinggi. Theories explaining this article is on the concept of regional development plan. Purwanti, Sumartono, \& Haryono (2015) say that the concept of regional development plan exists as a planning process to reach goals in doing changes toward a better society and community, better government, better environtment, especially in using various resources.

Initial problems in the city of Bukittinggi, raised a research question: How synchronized are the performance indicators in the 2016-2021 Bukittinggi RPJMD with the SDGs? The purpose of the study is to find the synchronization of performance indicators in the 20162021 Bukittinggi City RPJMD with SDGs.

\section{METHODOLOGY}

This research is qualitative research with a case study approach by Yin (2018). The results showed the uniqueness of the SDG synchronization case in the Bukittinggi RPJMD.

Data is collected through documentation. In the SDGs resolution document entitled Transforming our world: Agenda 2030 for Sustainable Development, there are 169 performance targets outlined per each SDGs target in 
the documents on pages 15 to 27 , and the 241 indicators have been compiled by the Ministry of National Development Planning. While in the Bukittinggi RPJMD document for 2016-2020, aligning efforts with The SDGs are mentioned in chapter IV, page 34 , and the government's performance indicators are fully spelled out in chapter V for each of the Bukittinggi City government missions. Figure 2 shows the research steps starting from coding, comparative analysis, to conclusion.

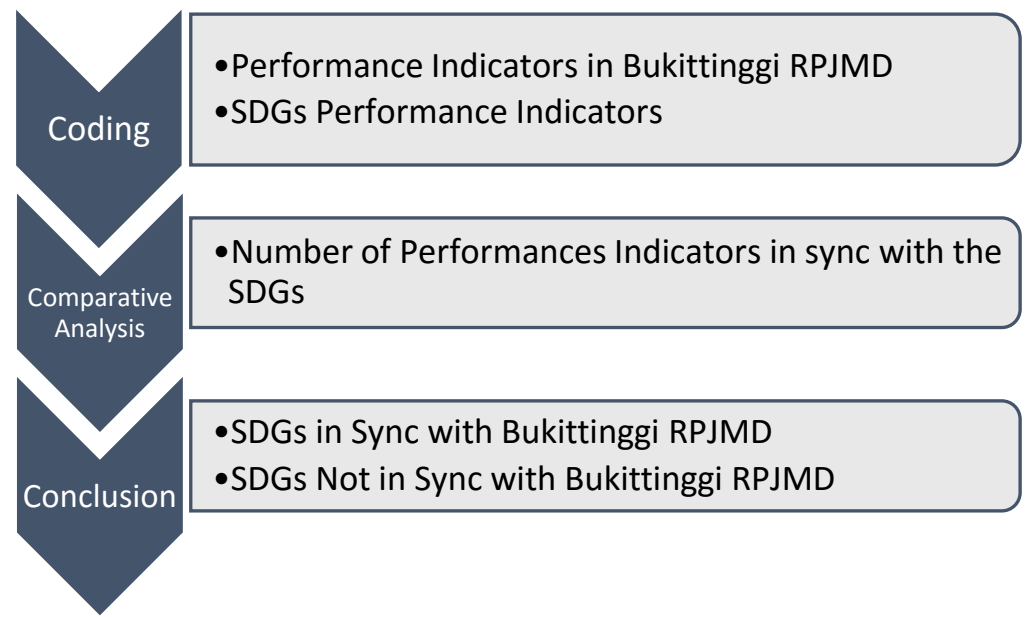

Source: Researcher's Analysis

Figure 2. Research Steps

\section{FINDINGS AND DISCUSSION}

To begin the elaboration of the missions and objectives listed in the Bukittinggi RPJMD.

findings, the following is a list of

Table 1. List of Missions and Goals of Bukittinggi City in the 2016-2021 RPJMD

\begin{tabular}{|c|c|c|}
\hline No. & Bukittinggi RPJMD Missions & Bukittinggi RPJMD Goals \\
\hline 1. & $\begin{array}{l}\text { To Develop and to Empower } \\
\text { Participation of Various Potential } \\
\text { Stakeholders (Government, } \\
\text { Business and Community) }\end{array}$ & $\begin{array}{l}\text { G1. To increase stakeholder participation in development ( } 3 \\
\text { objectives) }\end{array}$ \\
\hline 2. & $\begin{array}{l}\text { To Improve Government } \\
\text { Performance in a Professional, } \\
\text { Transparent, Accountable and } \\
\text { Entrepreneurial Spirit }\end{array}$ & G2. To realize good government governance (2 objectives) \\
\hline 3. & $\begin{array}{l}\text { To Improve the Development, } \\
\text { Arrangement, and Management of } \\
\text { City Facilities and Infrastructures in } \\
\text { An Environmentally Integrated } \\
\text { Manner }\end{array}$ & $\begin{array}{l}\text { G3. To increase the development of city facilities and } \\
\text { infrastructure in an environmentally integrated manner ( } 3 \\
\text { objectives) } \\
\text { G4. To improve urban spatial planning ( } 1 \text { objective) } \\
\text { G5. To make Bukittinggi a national and world heritage city (1 } \\
\text { objective) } \\
\text { G6. To realize traffic services and road transportation that are safe, } \\
\text { orderly, smooth and integrated ( } 1 \text { objective) } \\
\text { G7. To increase community and government institutions } \\
\text { preparedness for disasters ( } 1 \text { objective) }\end{array}$ \\
\hline
\end{tabular}




\begin{tabular}{|l|l|l|}
\hline 4. & $\begin{array}{l}\text { To Develop Urban Economic } \\
\text { Systems with Greater Usability }\end{array}$ & $\begin{array}{l}\text { G8. To enhance quality urban economic development (1 objective) } \\
\text { G9. To reducing poverty and unemployment (2 objectives) }\end{array}$ \\
\hline 5. & $\begin{array}{l}\text { To Improve the Quality of Tourism, } \\
\text { Education, Health, Trade, and } \\
\text { Services as well as Community }\end{array}$ & $\begin{array}{l}\text { G10. To increase tourist visits (1 objective) } \\
\text { G11. To have education services with quality and excellent } \\
\text { Social Welfare. }\end{array}$ \\
& $\begin{array}{l}\text { G12. To increase the degree of public health (3 objectives) } \\
\text { G13. To increase the added value of the trade and services sector } \\
\text { (2 objectives) } \\
\text { G14. To increase the welfare of the people of Bukittinggi (4 } \\
\text { objectives) }\end{array}$ \\
\hline
\end{tabular}

Source: Summarized from Table 5.5 in Bukittinggi RPJMD 2016-2021 (p. V-14 s.d. V-20)

Based on Table 1, there are five main missions of the City of Bukittinggi for 2016-2021. The five missions were pursued by making a set of 28 objectives in 14 goals. The first mission regarding efforts to develop and empower the participation of various potential stakeholders (government, business, and community), is elaborated through the achievement of 3 objectives in 1 development goal, namely increasing stakeholder participation in development. Furthermore, the second mission regarding efforts to improve government performance in a professional, transparent, accountable, and entrepreneurial spirit is elaborated through the achievement of 2 objectives in 1 development goal, which is to realize good government governance.

For the third mission regarding efforts to improve the development, arrangement, and management of city facilities and infrastructures in an integrated manner with an environmental perspective, there are seven objectives in 4 separate goals, namely to increase the development of city facilities and infrastructure in an environmentally integrated manner (3 objectives), to increase urban spatial planning (1 objective), to make Bukittinggi as a national and world heritage city (1 objective), to realize safe, orderly, smooth and integrated traffic services and roads (1 objective) and to increase the preparedness of the community and government institutions against disasters (1 objective).

The fourth mission of Bukittinggi City development in 20162021 is to develop a more efficient urban economic system. This mission is derived into three objectives in 2 goals, namely increasing the quality of urban economic development (1 objective) and reducing poverty and unemployment (2 objectives). For the goal of increasing the quality of urban economic development, the objective used to measure is increasing economic growth and equality, and reducing poverty and 
unemployment, the two objectives are reducing the poverty rate and decreasing the open unemployment rate.

Lastly, for the fifth mission regarding to efforts to improve the quality of tourism, education, health, trade, and services as well as social welfare services. There are 13 objectives in 5 goals in this mission. These objectives and goals consist of increasing tourist visits (1 objective), having quality education services and superior character (3 objectives), increasing the degree of public health (3 objectives), increasing the added value of the trade and services sector (2 objectives), and increasing the welfare of the people of Bukittinggi (4 objectives).

First, to increase tourist visits, the objective used to improve tourism services. Second, in order to have quality education services and superior character, the three objectives are increasing access to education services, improving the quality of education, and realizing the integration of religious values, customs, and culture in education. Third, for measuring the increase of the degree of public health, the three objectives used are improving the quality of health services, increasing control of transferable and nontransferable diseases and environmental health, and increasing equity and quality of health services and health resources. Forth, in reaching the goal of increasing the added value of the trade and services sector, the two objectives used are increasing added value itself and maintaining price stability. Finally, to increase the welfare of the people of Bukittinggi, the four objectives used to control are increasingly controlled population, improving gender equality and women's empowerment and child protection in social life, highering social protection of the community, and having a diversification of food consumption.

Out of the 14 goals and 28 objectives in Bukittinggi RPJMD, there are 48 performance indicators with different distributions to each objective. Table 2 provides the distribution of the performance indicators of Bukittinggi RPJMD.

Table 2. Bukittinggi RPJMD Objectives and Performance Indicators

\begin{tabular}{|l|l|l|}
\hline Goals No & Objectives of Bukittinggi RPJMD & Bukittinggi RPJMD Performance Indicators \\
\hline G1. & $\begin{array}{l}\text { G1.1 involving stakeholders in the process of } \\
\text { preparing regional development planning }\end{array}$ & $\begin{array}{l}\text { G1.1.1 Percentage of stakeholder proposals } \\
\text { accommodated in development planning }\end{array}$ \\
\cline { 2 - 3 } & $\begin{array}{l}\text { G1.2 increasing funding support for } \\
\text { development stakeholders }\end{array}$ & $\begin{array}{l}\text { G1.2.1 Ratio of corporate social responsibility to } \\
\text { APBD (regional budgets of revenue and }\end{array}$ \\
\hline
\end{tabular}




\begin{tabular}{|c|c|c|}
\hline & & $\begin{array}{l}\text { expenditures) direct expenditures in development } \\
\text { financing }\end{array}$ \\
\hline & $\begin{array}{l}\text { G1.3 involving stakeholders in overseeing } \\
\text { the implementation of regional development }\end{array}$ & $\begin{array}{l}\text { G1.3.1 Percentage of community organizations } \\
\text { active in the implementation and supervision of } \\
\text { development }\end{array}$ \\
\hline \multirow[t]{2}{*}{ G2. } & G2.1 implementing bureaucratic reform & $\begin{array}{l}\text { G2.1.1 SAKIP (Government Agency Performance } \\
\text { Accountability System) score } \\
\text { G2.1.2 LPPD (Local Government Organization } \\
\text { Report) rating } \\
\text { G2.1.3 RB (Bureaucratic Reform) Index } \\
\text { G2.1.4 BPK's opinion on regional financial } \\
\text { statements } \\
\text { G2.1.5 Public satisfaction index for public services }\end{array}$ \\
\hline & $\begin{array}{l}\text { G2.2 increasing entrepreneurship in } \\
\text { government management }\end{array}$ & G2.2.1 Ratio of regional financial independence \\
\hline \multirow[t]{3}{*}{ G3. } & G3.1 fulfilling the green city open space & G3.1.1 Percentage of Public Green Open Space \\
\hline & $\begin{array}{l}\text { G3.2 meeting the public facilities } \\
\text { environmental standards }\end{array}$ & $\begin{array}{l}\text { G3.2.1 Percentage of social facilities construction } \\
\text { meets environmental standards } \\
\text { G3.2.2 Percentage of general facilities construction } \\
\text { that meets environmental standards }\end{array}$ \\
\hline & $\begin{array}{l}\text { G3.3 meeting universal access targets } \\
\text { (sanitation, clean water, and slums) }\end{array}$ & $\begin{array}{l}\text { G3.3.1 Provision of drinking water is feasible } \\
\text { G3.3.2 Slums } \\
\text { G3.3.3 Percentage of proper sanitation }\end{array}$ \\
\hline G4. & G4.1 controlling the usage of urban space & G4.1.1 Suitability of the usage of urban space \\
\hline G5. & $\begin{array}{l}\text { G5.1 improving the preservation of cultural } \\
\text { reserves }\end{array}$ & G5.1.1 Percentage of cultural preservation \\
\hline G6. & G6.1 creating safe and smooth traffic & $\begin{array}{l}\text { G6.1.1 Regions coverage served by public } \\
\text { transportation } \\
\text { G6.1.2 Road in good condition }\end{array}$ \\
\hline G7. & $\begin{array}{l}\text { G7.1 increase the preparedness of the } \\
\text { community and government institutions } \\
\text { against disasters }\end{array}$ & G7.1.1 Percentage of disasters handled \\
\hline G8. & $\begin{array}{l}\text { G8.1 increasing economic growth and } \\
\text { equality }\end{array}$ & $\begin{array}{l}\text { G8.1.1 Economic growth } \\
\text { G8.1.2 Per capita GRDP } \\
\text { G8.1.3 Gini Index } \\
\text { G8.1.4 Investment Amount }\end{array}$ \\
\hline \multirow[t]{2}{*}{ G9. } & G9.1 reducing poverty rate & G9.1.1 Poverty level \\
\hline & G9.2 decreasing open unemployment rate & G9.2.1 Open unemployment rate \\
\hline G10. & G10.1 improving tourism services & $\begin{array}{l}\text { G10.1.1 Tourist visits } \\
\text { G10.1.2 Average length of stay of tourists }\end{array}$ \\
\hline \multirow[t]{3}{*}{ G11. } & $\begin{array}{l}\text { G11.1 increasing access to education } \\
\text { services }\end{array}$ & $\begin{array}{l}\text { G11.1.1 Expectancy of school years taken } \\
\text { G11.1.2 Average number of school years } \\
\text { G11.1.3 PAUD APK (gross participation number of } 3 \\
\text { - 6-year-old education) } \\
\text { G11.1.4 Dropout rates for elementary school and } \\
\text { middle school }\end{array}$ \\
\hline & G11.2 improving the quality of education & $\begin{array}{l}\text { G11.2.1 Percentage of elementary schools that have } \\
\text { A-level accreditation } \\
\text { G11.2.2 Percentage of junior high schools that have } \\
\text { A-level accreditation }\end{array}$ \\
\hline & $\begin{array}{l}\text { G11.3 realizing the integration of religious } \\
\text { values, customs and culture in education }\end{array}$ & $\begin{array}{l}\text { G11.3.1 Percentage of schools that implement local } \\
\text { content curriculum }\end{array}$ \\
\hline \multirow[t]{2}{*}{ G12. } & $\begin{array}{l}\text { G12.1 improving the quality of health } \\
\text { services }\end{array}$ & G12.1.1 Life expectancy \\
\hline & $\begin{array}{l}\text { G12.2 increasing control of transferable and } \\
\text { non-transferable diseases and } \\
\text { environmental health }\end{array}$ & $\begin{array}{l}\text { G12.2.1 Percentage of children aged } 0 \text { to } 11 \text { months } \\
\text { who received complete primary immunization } \\
\text { G12.2.2 The percentage of drinking water facilities } \\
\text { that meet the health requirements }\end{array}$ \\
\hline
\end{tabular}




\begin{tabular}{|l|l|l|}
\hline \multirow{2}{*}{ G13. } & $\begin{array}{l}\text { G12.3 increasing equity and quality of health } \\
\text { services and health resources }\end{array}$ & $\begin{array}{l}\text { G12.3.1 Percentage of accredited Puskesmas } \\
\text { (Society Health Centers) } \\
\text { G12.3.2 Percentage of essential health services } \\
\text { G12.3.3 Percentage of low-income families served }\end{array}$ \\
\hline \multirow{2}{*}{ G14. } & $\begin{array}{l}\text { G13.1 increasing the added value of the } \\
\text { trade and services sector }\end{array}$ & $\begin{array}{l}\text { G13.1.1 GRDP growth in the wholesale and retail } \\
\text { trade sector } \\
\text { G13.1.2 GRDP growth in the services sector }\end{array}$ \\
\cline { 2 - 4 } & G13.2 maintaining price stability & G13.2.1 Inflation rate \\
\cline { 2 - 4 } & $\begin{array}{l}\text { G14.1 increasing controlled population } \\
\text { empowerment and child protection in social } \\
\text { life }\end{array}$ & G14.1.1 Population growth rate \\
\cline { 2 - 3 } & $\begin{array}{l}\text { G14.3 highering social protection of the } \\
\text { community }\end{array}$ & $\begin{array}{l}\text { G14.3.1 City worthy for children achievement } \\
\text { G14.3.2 Reduced number of PMKS (People with } \\
\text { Social Welfare Problems) }\end{array}$ \\
\cline { 2 - 3 } & $\begin{array}{l}\text { G14.4 having a diversification of food } \\
\text { consumption }\end{array}$ & G14.4.1 Food range expectation score \\
\hline
\end{tabular}

After comparing the 17 goals of SDGs with a total of 48 performance indicators in the 14 goals of Bukittinggi
RPJMD, Table 3 provides the conclusion after synchronizing the indicators of Bukittinggi RPJMD and the SDGs.

Table 3. Synchronization Assessment for Bukittinggi RPJMD Indicators and SDGs

\begin{tabular}{|c|c|c|c|}
\hline $\begin{array}{l}\text { Goals } \\
\text { No }\end{array}$ & SDGs & Synchronization with Bukittinggi RPJMD Indicators* & $\begin{array}{l}\text { Achievements } \\
\text { In 2018** }\end{array}$ \\
\hline 1 & $\begin{array}{l}\text { End poverty in all its } \\
\text { forms everywhere }\end{array}$ & G9.1.1 Poverty level & $5.48 \%$ \\
\hline 2 & $\begin{array}{l}\text { End hunger, achieve } \\
\text { food security and } \\
\text { improved nutrition and } \\
\text { promote sustainable } \\
\text { agriculture }\end{array}$ & G14.4.1 Food range expectation score & $82.10 \%$ \\
\hline 3 & $\begin{array}{l}\text { Ensure healthy lives and } \\
\text { promote well-being for } \\
\text { all at all ages }\end{array}$ & $\begin{array}{l}\text { G12.1.1 Life expectancy } \\
\text { G12.2.1 Percentage of children aged } 0 \text { to } 11 \text { months who } \\
\text { received complete primary immunization } \\
\text { G12.2.2 The percentage of drinking water facilities that } \\
\text { meet the health requirements } \\
\text { G12.3.1 Percentage of accredited Puskesmas (Society } \\
\text { Health Centers) } \\
\text { G12.3.2 Percentage of essential health services } \\
\text { G12.3.3 Percentage of low-income families served }\end{array}$ & $\begin{array}{l}72.88 \\
\text { N/A } \\
92 \% \\
61.53 \% \\
\text { N/A } \\
72.89 \%\end{array}$ \\
\hline 4 & $\begin{array}{l}\text { Ensure inclusive and } \\
\text { equitable quality } \\
\text { education and promote } \\
\text { lifelong learning } \\
\text { opportunities for all }\end{array}$ & $\begin{array}{l}\text { G11.1.1 Expectancy of school years taken } \\
\text { G11.1.2 Average number of school years } \\
\text { G11.1.3 PAUD APK (gross participation number of } 3 \text { - 6- } \\
\text { year-old education) } \\
\text { G11.1.4 Dropout rates for elementary school and middle } \\
\text { school } \\
\text { G11.2.1 Percentage of elementary schools that have A-level } \\
\text { accreditation } \\
\text { G11.2.2 Percentage of junior high schools that have A-level } \\
\text { accreditation }\end{array}$ & $\begin{array}{c}14.92 \text { years } \\
72,88 \% \\
47,76 \% \\
0.12 \% \\
72.88 \% \\
61.53 \% \\
\end{array}$ \\
\hline 5 & $\begin{array}{l}\text { Achieve gender equality } \\
\text { and empower all women } \\
\text { and girls }\end{array}$ & G14.2.1 Gender empowerment index & $\mathrm{N} / \mathrm{A}$ \\
\hline 6 & $\begin{array}{l}\text { Ensure availability and } \\
\text { sustainable }\end{array}$ & $\begin{array}{l}\text { G3.3.1 Provision of drinking water is feasible } \\
\text { G3.3.2 Slums }\end{array}$ & $\begin{array}{c}92 \% \\
8.2 \text { ha }\end{array}$ \\
\hline
\end{tabular}




\begin{tabular}{|c|c|c|c|}
\hline & $\begin{array}{l}\text { management of water } \\
\text { and sanitation for all }\end{array}$ & G3.3.3 Percentage of proper sanitation & $96 \%$ \\
\hline 7 & $\begin{array}{l}\text { Ensure access to } \\
\text { affordable, reliable, } \\
\text { sustainable and modern } \\
\text { energy for all }\end{array}$ & Not available & - \\
\hline 8 & $\begin{array}{l}\text { Promote sustained, } \\
\text { inclusive and sustainable } \\
\text { economic growth, full } \\
\text { and productive } \\
\text { employment and decent } \\
\text { work for all }\end{array}$ & $\begin{array}{l}\text { G8.1.1 Economic growth } \\
\text { G8.1.2 Per capita GRDP } \\
\text { G8.1.3 Gini Index } \\
\text { G8.1.4 Investment Amount } \\
\text { G9.2.1 Open unemployment rate }\end{array}$ & $\begin{array}{c}6.2 \% \\
52.50 \mathrm{million} \\
0.34 \\
27 \% \\
7.15 \%^{\wedge}\end{array}$ \\
\hline 9 & $\begin{array}{l}\text { Build resilient } \\
\text { infrastructure, promote } \\
\text { inclusive and sustainable } \\
\text { industrialization and } \\
\text { foster innovation }\end{array}$ & $\begin{array}{l}\text { G6.1.1 Regions coverage served by public transportation } \\
\text { G6.1.2 Road in good condition } \\
\text { G7.1.1 Percentage of disasters handled }\end{array}$ & $\begin{array}{l}\mathrm{N} / \mathrm{A} \\
11.75 \mathrm{~km}^{\wedge} \\
100 \%\end{array}$ \\
\hline 10 & $\begin{array}{l}\text { Reduce inequality within } \\
\text { and among countries }\end{array}$ & $\begin{array}{l}\text { G8.1.1 Economic growth } \\
\text { G8.1.2 Per capita GRDP } \\
\text { G8.1.3 Gini Index } \\
\text { G8.1.4 Investment Amount }\end{array}$ & $\begin{array}{l}6.2 \% \\
52.50 \text { million } \\
0.34 \\
27 \%\end{array}$ \\
\hline 11 & $\begin{array}{l}\text { Make cities and human } \\
\text { settlements inclusive, } \\
\text { safe, resilient and } \\
\text { sustainable }\end{array}$ & $\begin{array}{l}\text { G3.1.1 Percentage of Public Green Open Space } \\
\text { G3.2.1 Percentage of social facilities construction meets } \\
\text { environmental standards } \\
\text { G3.2.2 Percentage of general facilities construction that } \\
\text { meets environmental standards } \\
\text { G4.1.1 Suitability of the usage of urban space }\end{array}$ & $\begin{array}{l}10.79 \% \\
\text { N/A } \\
67.94 \% \\
60 \% \\
\end{array}$ \\
\hline 12 & $\begin{array}{l}\text { Ensure sustainable } \\
\text { consumption and } \\
\text { production patterns }\end{array}$ & G14.4.1 Food range expectation score & $82.10 \%$ \\
\hline 13 & $\begin{array}{l}\text { Take urgent action to } \\
\text { combat climate change } \\
\text { and its impacts }\end{array}$ & $\begin{array}{l}\text { G3.1.1 Percentage of Public Green Open Space } \\
\text { G3.2.1 Percentage of social facilities construction meets } \\
\text { environmental standards } \\
\text { G3.2.2 Percentage of general facilities construction that } \\
\text { meets environmental standards }\end{array}$ & $\begin{array}{l}10.79 \% \\
\text { N/A } \\
67.94 \%\end{array}$ \\
\hline 14 & $\begin{array}{l}\text { Conserve and } \\
\text { sustainably use the } \\
\text { oceans, seas and marine } \\
\text { resources for } \\
\text { sustainable } \\
\text { development }\end{array}$ & Not available & - \\
\hline 15 & $\begin{array}{l}\text { Protect, restore and } \\
\text { promote sustainable use } \\
\text { of terrestrial } \\
\text { ecosystems, sustainably } \\
\text { manage forests, combat } \\
\text { desertification, and halt } \\
\text { and reverse land } \\
\text { degradation and halt } \\
\text { biodiversity loss }\end{array}$ & Not available & - \\
\hline 16 & $\begin{array}{l}\text { Promote peaceful and } \\
\text { inclusive societies for } \\
\text { sustainable } \\
\text { development, provide } \\
\text { access to justice for all } \\
\text { and build effective, } \\
\text { accountable and } \\
\text { inclusive institutions at } \\
\text { all levels }\end{array}$ & $\begin{array}{l}\text { G1.1.1 Percentage of stakeholder proposals } \\
\text { accommodated in development planning } \\
\text { G1.2.1 Ratio of corporate social responsibility to APBD } \\
\text { (regional budgets of revenue and expenditures) direct } \\
\text { expenditures in development financing } \\
\text { G1.3.1 Percentage of community organizations active in the } \\
\text { implementation and supervision of development } \\
\text { G2.1.1 SAKIP (Government Agency Performance } \\
\text { Accountability System) score }\end{array}$ & $\begin{array}{l}\text { N/A } \\
\text { N/A } \\
\text { BB }\end{array}$ \\
\hline
\end{tabular}




\begin{tabular}{|l|l|l|c|}
\hline & & G2.1.2 LPPD (Local Government Organization Report) rating & 29 \\
& & $\begin{array}{l}\text { G2.1.3 RB (Bureaucratic Reform) Index } \\
\text { G2.1.4 BPK's opinion on regional financial statements } \\
\text { G2.1.5 Public satisfaction index for public services }\end{array}$ & WTP \\
& & Not available & - \\
\hline 17 & $\begin{array}{l}\text { Strengthen the means } \\
\text { of implementation and } \\
\text { revitalize the Global } \\
\end{array}$ & & \\
& $\begin{array}{l}\text { Partnership for } \\
\text { Sustainable } \\
\text { Development }\end{array}$ & & \\
\hline
\end{tabular}

Source: *) Researchers' comparison results from the document of "Transforming our world: the 2030 Agenda for Sustainable Development" (pp. 15-27) and the Bukittinggi City RPJMD document (pp. V-14 to V-20). **) Bukittinggi LKIP/Government Institution Performance Report 2018 ^BPS/ Agency of Central Statistic West Sumatra

As can be seen from Table 3, it was found that four out of the 17 objectives in the SDG were not explained in the Bukittinggi's RPJMD. The four objectives are goal numbers $7,14,15$, and 17. This condition means that only $13 / 17$ SDG objectives are synchronized with those in the Bukittinggi RPJMD. The synchronization rate is calculated at $76 \%$.

The explanation behind this resurt is that, the 4 unsync goals are not in priority in Bukittinggi Development. Goal number 7 about sustainable energy, number 14 about sustainable sea resource, number 15 about sustainable forest management, and number 17 about global partnership are not available in the Bukittinggi RPJMD. This may be cause by the unavaiability of specific objects of the goals, for example: there is no sea and forest area to be sustainably managed by the city. Moreover, the city has not prioritized global partnership or sustainable energy in its development plan.

Furthermore, for indicators in each SDGs, we can say that the number of indicators in the Bukittinggi RPJMD is quite low compared to indicators in the SDGs. The Bukittinggi RPJMD only contains five missions, 14 goals, and 48 indicators. In each SDG goal synchronized with that in the Bukittinggi RPJMD, the indicator number ranges from 1 to 8 . The highest number of Bukittinggi RPJMD indicators are synchronized with SDG number 16. In these specific goals, the Bukittinggi RPJMD has eight coincident indicators. Meanwhile, the SDG goals that only have one synchronized indicators are goal number 1,2,5 and 12 .

Other SDGs are synchronized with $3,4,5$, or 6 indicators in the Bukittinggi RPJMD. The SDGs objectives that are synchronized with three indicators in the Bukittinggi RPJMD are numbers 4, 9, and 13 . 
Meanwhile, the SDG objectives that are synchronized with the four indicators in the Bukittinggi RPJMD are number 10 . Five indicators of Bukittinggi RPJMD are synchronized with SDGs number 8 , and six indicators are synchronized with SDGs number 3 and 4 . The total indicators in the Bukittinggi RPJMD that is synchronized with the SDGs goals are 38 indicators.

\section{CONCLUSION}

From the explanation in the previous section, we can conclude that the synchronization rate of SDGs objectives with those described in the Bukittinggi RPJMD is quite high, which is $76 \%$. Out of the 17 SDGs objectives, 13 are further elaborated in the Bukittinggi RPJMD indicators. Meanwhile, only four goals are out of sync. In each synchronized goal, only 38 indicators in the Bukittinggi RPJMD are synchronized, where each synchronized goal is further explained in 1 to 8 performance indicators in the Bukittinggi RPJMD.

\section{RECOMMENDATION}

Researchers can recommend Bukittinggi development planners to improve city development by increasing the number of indicators in development goals and synchronizing them further with those described in the SDGs.

\section{ACKNOWLEDGMENT}

The first researcher is a current master student in the Magister of Accountancy at Andalas University. She would like to thank her research advisors (second and third researcher) for fully contributing to perfecting the paper. She would also thank the Bukittinggi Government, especially the BAPPEDA (Local Research and Development Agency), in providing RPJMD and research inputs.

\section{REFERENCES}

Alfa, A. (2019). Analisis Keselarasan Tujuan Berkelanjutan/Sustainable Development Goals (TPB/SDGs) dengan Rencana Pembangunan Jangka Menengah Kabupaten Rokan Hulu Tahun 2016-2021. Selodang Mayang, 5(1), 23-32. Retrieved from https://ojs.selodangmayang.com/ind ex.php/bappeda/article/view/118

Badan Pemeriksa Keuangan RI. (2018). Performance Audit Report of the Preparedness for Implementation of SDGs in Indonesia. Retrieved from https://www.bpk.go.id/assets/files/o therpub/2019/otherpub_2019_154 9938379.pdf

Fauzi, A., \& Oxtavianus, A. (2014). The Measurement of Sustainable Development in Indonesia. Jurnal Ekonomi Pembangunan: Kajian Masalah Ekonomi Dan Pembangunan, 15(1), 68. https://doi.org/10.23917/jep.v15i1.1 24 
Hidayah, U., Mulatsih, S., \& Purnamadewi, Y. L. (2019). Analisis Kinerja dan Strategi Pengembangan UMKM Alas Kaki di Desa Pagelaran. Jurnal Benefita, 4(3), 435-448.

https://doi.org/10.22216/jbe.v4i3.42 32

Kementerian Luar Negeri Republik Indonesia. (2019). Indonesia's Commitment to Sustainable Development - 2030 Agenda for Sustainable Development. Retrieved from Kementerian Luar Negeri Republik Indonesia website: https://indonesia4unsc.kemlu.go.id/i ndex.php/our-priorities/indonesia-scommitment-to-sustainabledevelopment

Kementerian Perencanaan Pembangunan Nasional Republik Indonesia. (2018). Press Release: The Launching of National Action Plan (NAP) 2017-2019 to Achieve Sustainable Development Goals (SDGs). Jakarta: Kementerian Perencanaan Pembangunan Nasional Republik Indonesia.

Lidya, E. (2019). Strategi Kepala Sekolah Dalam Peningkatan Mutu Madrasah (Studi pada Madrasah Ibtidaiyah Negeri 1 Kota Prabumulih). Jurnal Ilmiah Bina Manajemen, 1(1), 7. Retrieved from http://journal.binadarma.ac.id/index .php/BINAMANAJEMEN/article/v iew/90

Lisna, V., Sinaga, B. M., Firdaus, M., \& Sutomo, S. (2013). Dampak Kapasitas Fiskal terhadap Penurunan Kemiskinan: Suatu Analisis Simulasi Kebijakan. Jurnal Ekonomi Dan Pembangunan Indonesia, 14(1), 1-26. https://doi.org/10.21002/jepi.v14i1. 433

Marlius, D., \& Putra, R. D. (2018). Strategi Pengembangan Sulam
Bayang. Jurnal Benefita, 3(2), 204218.

https://doi.org/10.22216/jbe.v3i2.34 94

Patiung, M. (2019). Analisis Permasalahan, Isu Strategis dan Kebijakan Pembangunan SDGs Kabupaten Mojokerto. Jurnal Ilmiah Sosio Agribis, 19(1), 33-52. https://doi.org/10.1017/CBO978110 7415324.004

Patole, M. (2018). Localization of SDGs through Disaggregation of KPIs. https://doi.org/10.3390/economies6 010015

Pribadi, R. E. (2017). Implementasi Sustainable Development Goals (SDGs) Dalam Meningkatkan Kualitas Pendidikan di Papua. EJournal Ilmu Hubungan Internasional, 5(3), 2017. Retrieved from ejournal.hi.fisipunmul.ac.id/site/

Purwanti, W. S., Sumartono, S., \& Haryono, B. S. (2015). Perencanaan Bank Sampah Dalam Rangka Pemberdayaan Masyarakat di Kecamatan Kepajen Kabupaten Malang. Reformasi, 5(1), 149-159. Retrieved from www.jurnal.unitri.ac.id

Salsabila, P. (2019, May). Baru 19 Provinsi Yang Miliki Rencana Aksi Pembangunan Berkelanjutan Berita Terkait: (May). Retrieved from https://m.bisnis.com/amp/read/2019 0502/45/917729/baru-19-provinsiyang-miliki-rencana-aksipembangunan-berkelanjutan

Saragih, J. P. (2014). Faktor Penyebab dan Kebijakan Pemerintah Provinsi Daerah Istimewa Yogyakarta Menghapus Kemiskinan. Jurnal Ekonomi \& Studi Pembangunan, 6(2), 139-155.

Sari, P. M., \& Stevani, S. (2020). Analysis of Sustainable Development Index in The West 
Sumatera. Economica Jurnal Program Studi Pendidikan Ekonomi, $\quad 8(2), \quad 12$. https://doi.org/http://dx.doi.org/10.2 2202/economica.2020.v8.i2.3976

Sofianto, A. (2019). Integrasi Target dan Indikator Sustainable Development Goals (SDGs) Ke Dalam Perencanaan Pembangunan Daerah di Jawa Tengah. Jurnal Litbang Provinsi Jawa Tengah, 17(1), 2541.

https://doi.org/10.36762/litbangjate ng.v17i1.769

Surya, R. Z. (2018). Pemetaan Keselarasan Indikator Tujuan Pembangunan Berkelanjutan/Sustainable Development Goals (TPB/SDGs) pada Rencana Pembangunan Kabupaten Indragiri Hilir. Jurnal BAPPEDA Selodang Mayang, 4(1), 8-18. Retrieved from https://ojs.selodangmayang.com/ind ex.php/bappeda/article/download/8 $4 / 91 /$
Tjandradewi, B. I., \& Srinivas, H. (2018). Localization of SDGs: Role of Local Governments. Yokohama City University Journal of Social Sciences, 70(2), 335-352. Retrieved from https://ycu.repo.nii.ac.jp/?action=re pository_action_common_downloa d\&item_id=1783\&item_no=1\&attri bute_id $=22 \&$ file_no $=1$

Wahyuni, R. N. T., \& Damayanti, A. (2014). Faktor-Faktor yang Menyebabkan Kemiskinan di Provinsi Papua: Analisis Spatial Heterogeneity. Jurnal Ekonomi Dan Pembangunan Indonesia, 14(2), 128-144. https://doi.org/10.21002/jepi.v14i2. 441

Yin, R. K. (2018). Case Study Research and Applications, Design and Methods. In SAGE Publication, Inc. (6th ed.). London: SAGE Publication, Inc. 